\title{
Consumption, habit formation, and savings: Evidence from a rural household panel survey
}

\author{
Aditya R. Khanal $^{1}$ | Ashok K. Mishra ${ }^{2}$ | S Nedumaran ${ }^{3}$
}

${ }^{1}$ College of Agriculture, Tennessee State University, Nashville, Tennessee

${ }^{2}$ W. P. Carey School of Business, Arizona State University, Mesa, Arizona

${ }^{3}$ International Crops Research Institute for the Semi-Arid Tropics, Hyderabad, Telangana, India

\section{Correspondence}

Aditya R. Khanal, Department of Agricultural and Environmental Sciences, College of Agriculture, Tennessee State University, 3500 John A. Merit Blvd, Nashville, TN 37209.

Email: akhanal1@tnstate.edu

\begin{abstract}
Protecting consumption from the effects of uninsured risk is vital for rural farming households, who tend to be poor and live close to subsistence level. Income uncertainty and habit formation play important roles in the consumption and savings. Variability in weather conditions has a strong linkage with variability in agricultural income in developing countries. This study analyzes consumption and saving decisions of rural farm households in India. Using household panel data for 4 years, we estimated consumption equation accounting for habit formation under income uncertainty. Our findings suggest an evidence for habit formation among rural households. Additionally, we found that both annual and seasonal weather risks significantly influence savings among rural households. Findings from this study also suggest a robust and vibrant farm economy and that the nonfarm economy could contribute to the economic well-being of rural farming households.
\end{abstract}

\section{1 | INTRODUCTION}

The life-cycle hypothesis implies that individuals plan their consumption and savings over a time horizon (life) and smooth their consumption in the best possible way. Under life-cycle or permanent income hypothesis (Friedman, 1957; Modigliani \& Brumberg, 1954), the consumption decision is an intertemporal allocation of resources available during a lifetime; the typical consumer maximizes utility by choosing an optimal level of resources, in each period, subject to lifetime budget constraints. A plethora of literature has examined this theory empirically (Flavin, 1981; Hall, 1978; Hall \& Mishkin, 1982; Kazarosian, 1997; Mishra, Uematsu, \& Powell, 2012). One of the challenges to the life-cycle hypothesis is the prospect of risk and uncertainty associated with income, which induces a demand for precautionary savings. Under liquidity constraints, however, 
consumption growth should be sensitive only to increases in income because consumers can smooth consumption by using savings if they expect future revenues to decrease.

In contrast, consumers with access to credit would follow a conventional life-cycle model prediction. However, empirical evidence reveals a deviation from this prediction. For example, Garcia, Lusardi, and Ng (1997) and Shea (1995) found that, for credit-unconstrained consumers, the level of consumption is affected by the negative realization in income. A plausible explanation for such an anomaly is the presence of asymmetric preferences. If preferences exhibit inertia, typically in the case of habit formation, studies (Deaton, 1992; Meghir \& Weber, 1996) show that households adjust their consumption, but slowly. Only a few studies have examined consumption decisions in the presence of habit formation and income uncertainty. ${ }^{1}$ For example, Alessie and Lusardi (1997) concluded that consumption depends not only on permanent income and income risk but also on past consumption - a case of habit formation. However, Guariglia and Rossi (2002) pointed out that a negative exponential utility function is not a good representation of preferences because it does not rule out the possibility of negative consumption. Guariglia and Rossi's (2002) presentation of the utility model is based on the generalization of Weil's (1993) model $^{2}$ and accounts for habit formation. Using this generalized model and panel data from British households, Guariglia and Rossi (2002) estimated changes in consumption. However, it should be noted that Guariglia and Rossi (2002) examined mostly urban households in England, and the income risk of urban households may be less than that of rural households, especially rural families involved in farming as a way of living. Recall that income from farming is risky and is significantly affected by uncertainties in weather conditions (Mishra \& Goodwin, 1997). Finally, weather risk is a primary source of fluctuations in income for rural households in developing countries (Morduch, 1995).

Interestingly, a few studies have examined the consumption-savings responses in the presence of uncertainties in farm income. For example, Kochar (1999) examined consumption-savings behavior in the face of crop income shocks in agriculture using longitudinal data. The author found that rural households may respond to crop income shocks by increasing their market (off-farm) hours of work. However, the author stresses that empirical results need to be confirmed with a larger sample size. Earlier, Paxson (1992) examined farmers' savings behavior as a response to rainfall shocks, with an assumption that variable rainfall resulted in variable household income in rural Thailand. With rainfall shocks as a proxy for income variability, the author's findings suggested that farmers have a higher propensity to save out of transitory income than farmers who do not experience rainfall shocks. However, Paxson (1992) stressed that income variability from panel data would have been a better indicator of income risk. We overcome this limitation in our study.

Finally, we cannot discount the importance of investigating the consumption-savings behavior of rural households in developing countries ${ }^{3}$ because it has both micro- and macro- level implications. For example, if the behavior is based on saving and non-saving (spending) rates of farmers in low-income countries like India, in particular, weather variability also plays a significant role in the income and consumption behavior. Additionally, in rural areas with low or no irrigation facilities (Hussain \& Hanjra, 2004), with a lack of proper storage and processing infrastructures (Abass et al., 2014), agricultural production depends highly on weather conditions. Further, Mondal et al. (2014) and Lobell, Schlenker, \& Costa-Roberts (2011) argue that India is one of the most vulnerable countries to future climate changes. Recall that variability in weather conditions has a strong linkage to variability in agricultural income in rural areas. Protecting consumption from weather's effects on agricultural profits is therefore vital for farming households living close to subsistence level-especially in India. If farm families can save and non-save (spend) while adjusting consumption by a one-to-one ratio, then policies concerning income variability may be less relevant. Additionally, farm households behave differently under weather and income uncertainties (Paxson, 
1992) than they behave when weather and income are certain. The share of savings out of consumption under uncertainty could be a good guideline for policies aimed at supporting rural households and attaining food security, income generation, and poverty alleviation. In that, we also cannot undermine the importance of an appropriate model and data to examine consumption-savings behavior.

Our study overcomes the limitation by examining the rural Indian households' consumptionsaving behavior and analyzing the effects of annual and seasonal weather risks-proxy for farm income risk (income risk from agricultural production) on savings. To accomplish this, we use panel data of 2009 to 2012 from rural Indian households. First, we estimate our model using a consumption-savings model, a Euler equation that accounts for habit formation. Through this model, we tested for precautionary savings motives. Second, we estimate households' actual savings behavior under annual and seasonal weather risks. Specifically, we estimate two savings models under two different risks by treating savings as a function of past savings, past incomes, weather risk, and demographic factors.

\section{2 | ROLE OF WEATHER IN INDIAN AGRICULTURE}

Located to the southeast of the Eurasian countries, India is a fast-growing country. Its population is growing by 1.2 percent a year based on 2016 statistics (the population in 2016 is 1.3 billion). However, about 69 percent of the population still lives in rural communities, and the majority of rural households (55 percent) depend directly on agriculture for their livelihood (Government of India, 2013). Agriculture is an important sector of the economy, accounting for about 14 percent of GDP and 11 percent of the country's exports. About 56 percent of India's land mass is agricultural, and only 43 percent is net cultivated area; 60 percent of India's total cropped area is still rain-fed and therefore depends on the monsoon (Kumar et al., 2014). The impact of climate change on agricultural production can adversely affect global food security in four ways: food availability, food accessibility, food utilization, and food system stability. High variations in environmental factors such as temperature and rainfall, for example, can negatively affect crop growth, although certain crops may be positively affected by changes in these environmental factors. Therefore, changes in climatic variables can have a negative impact on output, income, and food security (Greg, Bnam, William, \& Duru, 2011).

Although food grain production has grown substantially, the weather pattern in India varies significantly. India experiences significant annual variations in summer monsoon rainfall. Variability in rainfall is regarded as the primary cause of yearly fluctuations in crop yields; it is more relevant when considering food grain production on an aggregate scale. More subtle variations in weather during critical phases of crop development also can have a substantial impact on crop yields. Additionally, cultivated areas are subject to a broader range of influences, including changes in agricultural commodity prices, costs of input, and availability of irrigation. Finally, climate may have indirect and possibly lagged influences on harvested and cultivated areas (Khanal, Mishra, \& Bhattarai, 2017).

Monsoon season starts in late June or July, and Indian agriculture then highly depends on the southwest monsoon. The southwest monsoon is critical to Kharif crops (those with a growing season from June to September), which account for more than 50 percent of India's food grain production and more than 65 percent of its oilseed production. Variability in the southwest monsoon over India has a strong impact on the variability of aggregate Kharif food grain production (Gadgil, 1996; Webster et al., 1998). 
The Rabi growing season starts after the summer monsoon season and continues until the following spring or early summer. Rainfall occurring at the end of the monsoon season provides stored soil moisture and irrigation water for Rabi crops, which are sown in the post-monsoon season (October-November). Therefore, the summer monsoon is responsible for both Kharif and Rabi crop production in India. The northeast (winter) monsoon contributes substantial rainfall in much of states like Tamil Nadu and Andhra Pradesh, permitting production of rain-fed crops during the Rabi season. More subtle fluctuations in weather during critical phases of crop development also can have a substantial impact on yields.

For both seasons, weather variability is regarded as the primary cause of year-to-year fluctuations in yields. Shortfalls in rainfall can reduce irrigation water supplies, leading to reduced areas under irrigated crops and potentially increased areas under rain-fed crops in the subsequent season. Variations in rainfall during the monsoons affect India's total food grain yield and the country's economy (Krishna, Rupa, Ashrit, Deshpande, \& Hansen, 2004). The authors point out that more than 60 percent of the cropped area in India still depends solely on monsoon rainfall, with the poorest farmers practicing rain-fed agriculture. Finally, Krishna et al. (2004) conclude that crop response to monsoon rainfall does have some predictability. A difference in rainfall or temperature from normal conditions reduces yield and the net income of farmers.

\section{3 | LITERATURE REVIEW}

\section{1 | Consumption and habit formation}

Habit formation was first introduced in the context of demand analysis (Pollack, 1970) and is mainly of two types-myopic and rational. In myopic habit formation, consumers are not aware of the effects that their current consumption decisions will have on their future marginal rates of substitution between goods. Consequently, their behavior may be time-inconsistent. In rational habit formation, consumers are aware of the habit-forming effects of their current consumption. Empirically, findings are mixed-for and against-regarding the predictions of lifecycle models. Among reported anomalies from the prediction of the life-cycle model, habit formation is one of the convincing arguments to justify consumers' slow adjustments (Meghir \& Weber, 1996). Habit formation relies on the idea that one's past consumption might affect the utility one obtains from current consumption. Moreover, some anomalies in macro-level models that contrast with permanent income prediction can be resolved when allowing for habit formation. For example, Carroll, Overland, and Weil (2000) showed that "high growth leads to high saving"- a consistent finding with the standard growth model-and is realized when accounting for habit formation. In contrast, results were inconclusive in the absence of habit formation information. Although interest has been increasing in habit formation in theory and evidence based on aggregate data, a limited number of studies have used micro-level data to examine this behavior.

One common approach in microeconometric studies to test for the presence of habit formation is through the Euler equation. Guariglia and Rossi (2002) derived a closed-form solution of the model under uncertainty while accounting for habit formation. They also tested the model using a British household panel survey and found significant evidence of habit formation. Rhee (2004) and Alessie and Teppa (2010) found evidence of habit formation using household-level data from Korea and the Netherlands, respectively. In contrary, Dynan (2000) used household-level Panel Study of Income Dynamics (PSID) data, 1974 to 1987, in the United States and found no evidence of habit formation. ${ }^{4}$ However, it should be noted that a limited number of studies 
(Guariglia \& Rossi, 2002; McKenzie, 2001) have taken habit formation into account when examining consumption and precautionary savings motive. Our study aims to contribute to this limited empirical literature using panel survey data from rural Indian households. To the best of our knowledge, none of the previous studies have examined the consumption response and precautionary savings behavior in the presence of risks in agricultural and nonagricultural incomes. Additionally, the period analyzed is of particular importance because both consumption and income have grown rapidly in India over the two decades: 1990s and 2000s.

\subsection{Consumption and savings in rural India}

The economic reforms following the macroeconomic crisis of 1991 to 1992 marked a significant change in India's economic landscape. Growth certainly has accelerated, with GDP per capita rising by 4 to 5 percent since 1991. However, Datt and Ravallion (2002) question the gains from higher growth rates when it comes to the rural population. Following the economic reforms initiated in 1991, savings performance has been the subject of a prominent policy debate in India (Athukorala \& Sen, 2002). People in both rural and urban areas of Asia prefer to save more in physical assets than in financial assets (Jha, Prasad, \& Terada-Hagiwara, 2009). Indian data shows an overwhelming preference for household savings in physical assets rather than financial ones, owing to better returns. For instance, physical savings increased from 53 percent of total savings in 2009 to 2010 to about 68 percent of total savings in 2012 to 2013. The national savings rate has risen consistently. Private savings comprise a greater share of the national savings than do public savings, which have been declining since the 1980s. Economic growth, per capita income and consumer buying capacity has accelerated sharply since the 1990s (Landes \& Burfisher, 2009). However, financial savings as a percentage of GDP fell from 10 percent in 2004 to 2005 to about 7 percent in 2012 to 2013.

However, the national growth, savings, and consumption figures may not reflect those of the farming sector, because this sector has poor economic performance. For instance, in rural areas, 73 percent of savings is on land, and 21 percent is in buildings. ${ }^{5}$ After investing in land and buildings, people prefer to invest in livestock and poultry, agricultural machinery and equipment, and nonfarming business equipment before they think of investing in financial assets. It comes as a no surprise that a reduction in pervasive rural poverty in India is subject to question despite an overall economic growth (Landes \& Burfisher, 2009). Spending on food accounts for 47 percent of India's private consumption expenditures on goods and services, but in rural households, it accounts for a larger share of total household spending (Khanal, Mishra, \& Keithly, 2016). There are significant differences in rural and urban sector growth, consumption, and expenditures. For example, 75 percent of the rural households earn less than Rs. 5,000 per month ${ }^{6}$ and the rural poverty rate is about 26 percent, compared with 25 percent of urban households earning Rs. 11,143 per month and only 14 percent urban poverty rate (Government of India, 2011). Although monthly per capita consumption in urban India grew 54 percent in the 1993 to 2012 period, growth in per capita consumption in rural India over the same period was significantly lower at about 37 percent (Government of India, 2013, 2014). However, rural India has experienced a higher growth in per capita consumption than urban India has experienced. For instance, Figure 1 shows that the growth in monthly per capita consumption in rural and in urban India, over 2005/2006 to 2012 period, has been very close (22 percent vs. 27 percent, respectively, Government of India, 2014). Additionally, demand for precautionary savings for rural Indian households is expected to rise with uncertainties in future income. In rural agricultural households, uncertainties mainly come from variabilities in both agricultural and nonagricultural income. 


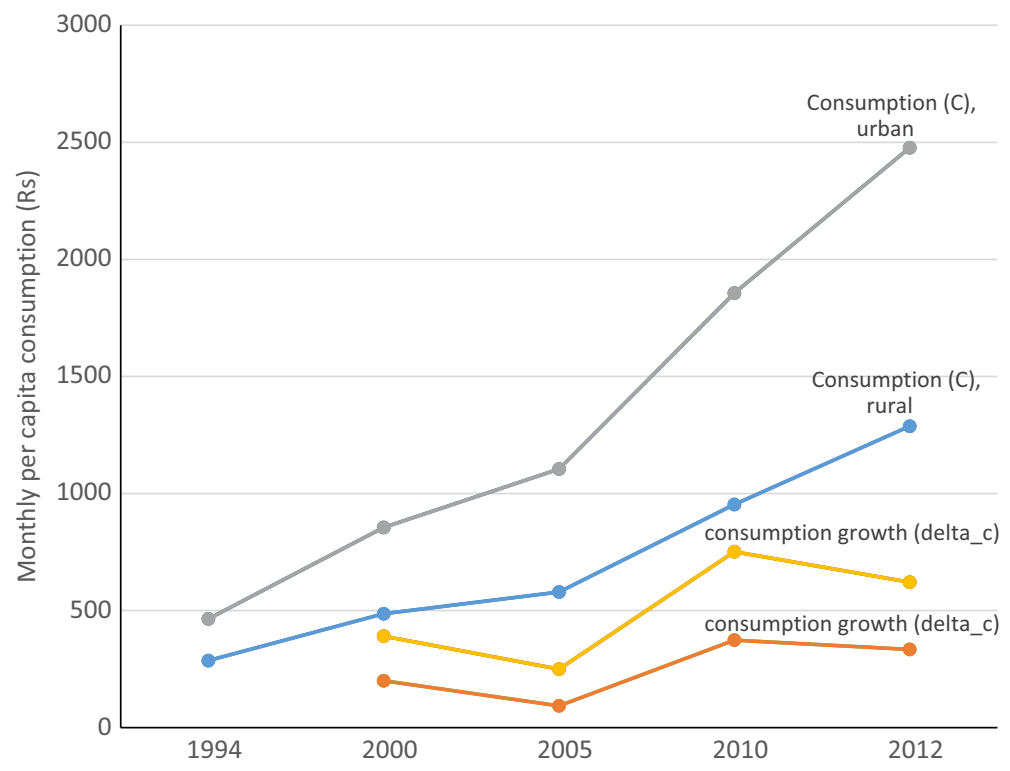

FIG URE 1 Monthly per capita consumption and change in consumption growth in rural and urban India Source: NSS Report No. 555, National Sample Survey Office (Government of India, 2014).

\section{4 | THEORETICAL FRAMEWORK}

Let us assume that the household maximizes the utility function $U$, a constant relative risk aversion (CRRA) in which preferences are characterized by constant elasticity of intertemporal substitution (equal to $1 / \alpha$ ). Let us denote consumption, total assets (resources), and income at time $t$ as $c_{t}, a_{t}$, and $y_{t}$, respectively. Let $\delta$ and $R$ represent subjective discount and interest factors, respectively. The utility function can be shown as:

$$
U\left(c_{t}^{*}, c_{t+1}^{*}, \ldots \ldots \ldots\right)=\left\{(1-\delta) \sum_{s=0}^{\infty} \delta^{s}{c^{*}}_{t+s}{ }^{1-\alpha}\right\}^{\frac{1}{1-\alpha}} .
$$

Equation 1 can be represented in the following recursive form:

$$
\begin{gathered}
U\left(c_{t}^{*}, c_{t+1}^{*}, \ldots \ldots\right)=V\left\{c_{t}^{*} ; U\left(c_{t+1}^{*}, c_{t+2}^{*}, \ldots \ldots\right)\right\} \\
=\left\{(1-\delta) c_{t}^{* 1-\alpha}+\delta\left[V\left(c_{t+1}^{*}, c_{t+2}^{*}, \ldots \ldots\right)\right]^{1-\alpha}\right\}^{\frac{1}{1-\alpha}} .
\end{gathered}
$$

An individual household maximizes utility function subject to the yearly budget constraint.

$$
a_{t+1}=R\left(a_{t}-c_{t}\right)+y_{t+1},
$$

$\lim _{i \rightarrow \infty} R^{-i} a_{t+i} \geq 0$ by transversality condition.

Let us now introduce uncertainty into the model by assuming a stochastic process for income that takes the following $\operatorname{AR}(1)$ with drift form.

$$
y_{t+1}=\rho y_{t}+(1-\rho) \hat{y}+\varepsilon_{t+1} .
$$

$y_{t+1}$ and $y_{t}$ represent incomes in $t+1$ and $t$ periods, respectively. $\hat{y}$ is the predicted component of income, and the error term $\varepsilon_{t+1}$ is assumed to be i.i.d. normally distributed with mean 0 and variance $\sigma^{2}$ Now assume that $\beta$ represents the attitudes towards the risk, a constant positive 
coefficient of absolute risk aversion. Similar to Weil (1993), we also assume isoelastic utility preferences intertemporally but exponentially in risk dimensions. In this framework, the certainty equivalent utility of a lottery yielding a random utility $U^{\prime \prime}$ is $U^{\prime}$ as follows:

$$
\mathrm{e}^{-\beta U^{\prime}}=E\left\{\mathrm{e}^{-\beta U^{\prime \prime}}\right\}
$$

where $E$ represents expectation conditional on information available at time $t$, which follows: $U^{\prime}=\ln E \mathrm{e}^{-\beta U^{\prime \prime}} /-\beta$.

Let us use the notation $U^{\prime}\left(c_{t}^{*}, \widetilde{c_{t+1}^{*}}, \widetilde{c_{t+2}^{*}}, \ldots \ldots \ldots\right)$ as the certainty equivalent of the time $t+1$ utility, conditional on the information available at time $t$. Now, the utility maximization can be shown as a recursive way, which representing an aggregation of the current consumption $c_{t}^{*}$ and the certainty equivalent of future utility.

$$
U\left(c_{t}^{*}, \widetilde{c_{t+1}^{*}}, \widetilde{c_{t+2}^{*}}, \ldots \ldots . . .\right)=V\left\{c_{t}^{*} ; U^{\prime}\left(\widetilde{c_{t+1}^{*}}, \widetilde{c_{t+2}^{*}}, \ldots \ldots\right)\right\} .
$$

The optimal solution of the above equation subject to budget constraint and transversality condition can be characterized by a value function in Bellman equation framework

$$
\begin{aligned}
W\left(a_{t}, y_{t}, c_{t-1}\right)= & \max _{c_{t}>0}\left\{\left\{(1-\delta)\left(c_{t}-\gamma c_{t-1}\right)^{(1-\alpha)}\right\}\right. \\
& \left.+\delta\left[\frac{\operatorname{InE} \exp \left\{-\beta W\left[R\left(a_{t}-c_{t}\right)+y_{t+1}, c_{t}\right]\right\}}{-\beta}\right]^{1-\alpha}\right\}^{\frac{1}{1-\alpha}} .
\end{aligned}
$$

The optimization solution of this Bellman equation leads to the following closed form for $c_{t}$ (for detailed derivation, see Guariglia \& Rossi, 2002).

$$
c_{t}=\left[1-R^{\frac{(1-\alpha)}{\alpha}} \delta^{\frac{1}{\alpha}}\right]\left(1-\frac{\gamma}{R}\right)\left[a_{t}+\frac{1}{R-\rho} \rho y_{t}+\frac{1}{R-\rho} \frac{R}{R-1}\left((1-\rho) \hat{y}+\varepsilon^{*}\right)\right]+\left(R^{\frac{(1-\alpha)}{\alpha}} \delta^{\frac{1}{\alpha}}\right) \gamma c_{t-1} .
$$

This generalized consumption function represents three components: level of income and total resources component $\left(\mathrm{a}_{\mathrm{t}}, \mathrm{y}_{\mathrm{t}}, \hat{y}\right)$; precautionary savings component $\left(\varepsilon^{*}\right)$; and past consumption component, representing habit formation (the term in $c_{t-1}$ ). From the above equation, note that if $\gamma=0$, preferences exhibit no habits, while a higher $\gamma$ indicates the higher importance of habits in influencing optimal consumption. Also, note that under no uncertainty and no habit formation $(\gamma=0)$, we are left with the usual closed-form solution for consumption obtained in life-cycle/permanent income model. The precautionary component is given by:

$$
\varepsilon^{*}=-\frac{\sigma^{2}}{2}\left[\frac{\beta R}{R-\rho}\right]\left[(1-\delta)^{\frac{1}{1-\alpha}}\left(1-\frac{(\delta R)^{\frac{1}{\alpha}}}{R}\right)^{\frac{\alpha}{\alpha-1}}\left(\frac{R-\gamma}{R}\right)\right] .
$$

As we can notice from Equation 9, the presence of habits affects optimal consumption not only through $c_{t-1}$, but also indirectly through making the precautionary component smaller. To derive an empirical Euler equation of consumption in simple form, assume $\delta R=1$. Now, we obtain:

$$
\Delta c_{t+1}=\gamma \Delta c_{t}+\frac{R-1}{R}\left(1-\frac{\gamma}{R}\right)\left[\left(\frac{R}{R-\rho}\right)\left(\varepsilon_{t+1}-\varepsilon^{*}\right)\right],
$$

where $\varepsilon_{t+1}$ is the residual obtained from the income process described in Equation 4 and $\varepsilon^{*}$ is the precautionary savings component. Equation 9 suggests that $\varepsilon^{*}$ is negative, indicating that precautionary savings affect changes in consumption positively, that is, consumers face uncertainty by postponing consumption. 


\section{ECONOMETRIC SPECIFICATION}

Based on the theoretical framework described in Equation 10, consumption changes in time $t$ essentially depend on consumption changes in time $t-1$ and the precautionary component, $\varepsilon^{*}$. A special case of models under sequential exogeneity restrictions is autoregressive models. As shown in Equation 4, we assume an $\mathrm{AR}(1)$. Following the theoretical equation, we estimate the following Euler equation:

$$
\Delta c_{i t}=\alpha+\gamma \Delta c_{i(t-1)}+\beta_{1} V A R_{i t}+\beta_{2} X_{i t}+v_{i}+v_{t}+e_{i t},
$$

where $\Delta$ is the first-difference operator. $\Delta c_{i t}$ and $\Delta c_{i(t-1)}$ represents household $i$ 's average monthly consumption on food as a proxy for total nondurable household consumption in period $t$ and $t-1$, respectively. $V A R_{i t}$ is the proxy for $\varepsilon^{*}$, income risk faced by the household $i$ at time $t$. In our empirical estimation, we will estimate separately the variability in labor (off-farm) income and the variability in agricultural income. The equation shows that the precautionary component of consumption is a function of $\sigma^{2}$ (Equation 9), which represents the variance of the residuals in the income process described in Equation 4.

In computing $V A R_{i t}$, we obtain the residuals from random effects regression of the household's labor (off-farm) earnings on lagged earnings, age, education, gender, regional dummies, occupational dummies, and the interaction of the education and occupational dummies with age. We then calculate the variance of these residuals in three or more years preceding and including year $t$. Utility function is likely to vary with demographics, family characteristics, and other socioeconomic variables since these may lead to shifts and variations in tastes. Therefore, we will add variables $\left(X_{i t}\right)$ on the right-hand side of the Euler equation. Finally, Equation 11 shows three components of the error term: a household-specific term $v_{i}$, a time-specific term $v_{t}$, and an idiosyncratic term $e_{i t}$. We account for the time-specific effect by including year dummies in all our specifications. We compute the Euler equation using dynamic panel data models-pooled ordinary least squares (OLS), within-group estimator and generalized method of moments (GMM). We compute the difference GMM and the system GMM estimators designed and mostly suited for "small T, large N" (small time period) panel data analysis.

The pooled OLS method ignores time dimension and treats the data as cross-sectional by pooling across years. In the context of panel data, we usually must deal with unobserved heterogeneity. One of the common methods to deal with unobserved heterogeneity is to do the within (demeaning) transformation, the one-way fixed effect models, or by taking first differences. However, a difficulty arises owing to demeaning in "small $\mathrm{T}$, large $\mathrm{N}$ " type of panels, in particular, because demeaning subtracts individual's mean value of a dependent variable from each of the independent variables that may create a correlation between regressors and error term (Nickell, 1981). Our estimators embody the assumptions of habit formation (the process is dynamic with the current realization as a dependent variable, consumption, is influenced by past ones), and idiosyncratic disturbances are uncorrelated across individuals. We tested for serial correlation, for used instruments, and for over-identifying restrictions.

Additionally, the ability of first differencing to remove unobserved heterogeneity has been developed for dynamic panel data (DPD) models-difference GMM (Arellano-Bond estimators, Arellano \& Bond, 1991) and system GMM estimators (Arellano \& Bover, 1995; Blundell \& Bond, 1998). A key feature of the Arellano-Bond and Arellano-Bover/Blundell-Bond estimators is that they allow internal instruments (based on lagged values of the instrumented variable(s)) as well as external instruments (other instruments in addition to lagged value). These embody the "first-differencing" method that essentially removes the error term and its associated omitted-variable bias. ${ }^{7}$ 
T A B L E 1 Variable definition and summary statistics, rural India, 2009-2012

\begin{tabular}{|c|c|c|c|c|c|}
\hline Variables & Definition & Mean & $S D$ & Min & $\operatorname{Max}$ \\
\hline Consumption $\left(c_{i t}\right)$ & Total annual household consumption ('000) & 79.19 & 72.39 & 2.73 & $1,469.80$ \\
\hline $\begin{array}{l}\text { Consumption } \\
\text { growth }\left(\Delta c_{i t}\right)\end{array}$ & Annual food consumption, first difference & 9.64 & 73.05 & -1121.61 & 805.24 \\
\hline Owned plots & Total value of the plots owned ('000) & 358.73 & 586.85 & 0.000 & 10,800 \\
\hline Income & Total annual household Income ('000) & 147.09 & 217.63 & 0.000 & $3,027.82$ \\
\hline $\begin{array}{l}\text { Income uncertainty }^{\mathrm{a}} \\
\left(V A R_{i t}\right)\end{array}$ & $\begin{array}{l}\text { Residuals from random effect regressions } \\
\text { of the household's income generation } \\
\text { process (for precision, divided } \\
\text { by } 1,000 \text { ) }\end{array}$ & 62.88 & 400.29 & $4.9 \times 10^{-8}$ & $7,967.90$ \\
\hline Family size & Number of family members in a household & 5.19 & 2.31 & 1 & 24 \\
\hline Female & $\begin{array}{l}=1 \text { if household head is female, } \\
0 \text { otherwise }\end{array}$ & 0.30 & 0.46 & 0 & 1 \\
\hline Age & Age of the head of household, years & 49.13 & 12.48 & 16 & 88 \\
\hline Education & Years of education, head of household & 4.94 & 4.75 & 0 & 18 \\
\hline Year 2009 & $=1$ if year is 2009 & 0.19 & 0.40 & 0 & 1 \\
\hline Year 2010 & $=1$ if year is 2010 & 0.27 & 0.44 & 0 & 1 \\
\hline Year 2011 & $=1$ if year is 2011 & 0.27 & 0.44 & 0 & 1 \\
\hline Year 2012 & $=1$ if year is 2012 & 0.27 & 0.44 & 0 & 1 \\
\hline Part II & & & & & \\
\hline Savings & $\begin{array}{l}\text { Total annual savings (total income less } \\
\text { total food and nonfood expenditures) } \\
\text { in rupees ('000) }\end{array}$ & 111.56 & 239.73 & -146.98 & $2,965.44$ \\
\hline Farming occupation & $=1$ if farming is the main occupation & 0.41 & 0.49 & 0 & 1 \\
\hline Service occupation & $=1$ if service is the main occupation & 0.11 & 0.32 & 0 & 1 \\
\hline Off-farm work & $\begin{array}{l}=1 \text { if participated, earned nonfarm } \\
\text { income }\end{array}$ & 0.42 & 0.49 & 0 & 1 \\
\hline Risk related variables & & & & & \\
\hline Weather risk (annual) & $\begin{array}{l}\text { Coefficient of variation based on } \\
\text { monthly rainfall data in a year }\end{array}$ & 0.61 & 0.18 & & \\
\hline $\begin{array}{l}\text { Seasonal variability: } \\
\text { Rabi }\end{array}$ & $\begin{array}{l}\text { Coefficient of variation in monthly } \\
\text { rainfall during Rabi seasonal }{ }^{b}\end{array}$ & 1.61 & 0.82 & 0.00 & 2.45 \\
\hline $\begin{array}{l}\text { Seasonal variability: } \\
\text { Kharif }\end{array}$ & $\begin{array}{l}\text { Coefficient of variation in monthly } \\
\text { rainfall during Kharif seasonal }\end{array}$ & 0.84 & 0.33 & 0.00 & 2.24 \\
\hline$N$ & \multicolumn{5}{|c|}{3,575} \\
\hline
\end{tabular}

Note. $S D=$ standard deviation. ${ }^{a} V A R_{i t}$ is the residuals from a random effects regression of the household's toal annual earnings. Residuals are obtained from regression of the household's total earnings (annual income) on lagged earnings, age of the household head, gender, education, distance to work place, occupational dummies, and interactions of occupations with age and education. This is the first stage regression procedure and results are presented in Appendix Table A1. ${ }^{b}$ Coefficient of variation (CV) of rainfall is computed from monthly village-level rainfall data for respective years. CV of Kharif season computed from the monthly rainfall data from May to October; CV of Rabi season computed from the monthly rainfall data from November to March. 
The Arellano-Bond estimator sets up a GMM problem in which the model is specified as a system of equations, one per period, where the instruments applicable to each equation differ (for instance, in later time periods, additional lagged values of the instruments are available). A potential weakness in the Arellano-Bond estimator was revealed in later work by Arellano and Bover (1995) and Blundell and Bond (1998). The lagged levels are often rather poor instruments for first-differenced variables, especially if the variables are close to a random walk. Their modification of the estimator includes lagged levels as well as lagged differences. Although the ArellanoBond estimator is often referred as difference GMM method, the Arellano-Bover/Blundell-Bond estimators are commonly termed System GMM. Difference GMM and System GMM methods are the most suitable methods developed so far for dynamic panel data with unobserved heterogeneity. As these estimators are instrumental variables methods, it is of particular importance to evaluate the Sargan-Hansen test results when they are applied. Another important diagnostic is the AR test for autocorrelation of the residuals. By construction, the residuals of the differenced equation should possess serial correlation, but if the assumption of serial independence in the original errors is warranted, the differenced residuals should not exhibit significant AR(2) behavior. If a significant AR (2) statistics is encountered, the second lag of endogenous variables will not be appropriate instruments for their current values.

As shown, $V A R_{i t}$ in Equation 11 is the proxy for $\varepsilon^{*}$, and $\varepsilon^{*}$ can be a representation of the labor income risk faced by the household $i$ in year $t$. The precautionary component of consumption is in fact a function of $\sigma^{2}$, which represents the variance of the residuals in the labor income process. As described in the data section, $V A R_{i t}$ is the variance of the residual and is obtained from the random effects regression of the labor income process. As the utility function is likely to vary with variables such as family size, education, gender, and age of the household head, which represent shift in taste, we included these factors as independent variables in the Euler equation.

In the second part of the paper, we estimated actual savings equations and analyzed factors influencing saving decisions for rural households with special attention to the behaviors under income variability under weather risks. The savings equation under risk can be represented as:

$$
S_{i t}=\beta_{0}+\beta_{1} S_{i, t-1}+\beta_{1} Y_{i, t-1}+C V_{i t}+Z_{i t}+\varepsilon_{i t} .
$$

where $S_{i t}$ represents savings of household $i$ in year $t, S_{i, t-1}$ and $Y_{i, t-1}$ represent lagged savings and incomes, $C V_{i t}$ represents weather risk and variability, and $Z_{i t}$ represents all other socioeconomic and demographic variables influencing the household's savings decision.

\section{DATA AND VARIABLES}

To conduct an empirical analysis in this study, we obtained rural household-level panel data from India for the years 2009 to 2012 collected by the International Crops Research Institute for SemiArid Tropics (ICRISAT) as part of the Village Dynamics Study in South Asia (VDSA) program. ICRISAT micro-level data contains information on production, price, markets, climate, and socioeconomic aspects from representative villages across India. This study uses farm households from 18 villages in five states, namely Andhra Pradesh (AP), Madhya Pradesh (MP), Maharashtra $(\mathrm{MH})$, Gujarat (GJ), and Karnataka (KT). The villages were selected randomly to be representative of different agro-ecological zones in India. In each village, 40 sample households were selected representing households in the labor/landless, small farm, medium farm, and large farm categories (see Jodha, Asolan, \& Ryan, 1977). These initial 40 households along with some additional 
households in some years were surveyed and tracked over the years. The households analyzed in this study are rural households that represent mainly the farm households in the low-income economy. Households rely primarily on various agricultural incomes but also have, to different degrees, nonagricultural or off-farm income.

The information on ICRISAT data is presented in various modules. Consumption of food and nonfood items are shown under a transaction module. Total annual incomes, farm and nonfarm incomes, livestock, and land holdings, and other demographic information are collected under a general endowment model. The consumption variable in this study is the total annual household consumption. The uncertainties in household income (income uncertainty, $V A R_{i t}$ ) in the data set are the residual from a random effects regression representing household's income earnings equations. To obtain this, we first estimated the household's income model by regressing household income (earnings) on lagged earnings; age of the household head, gender, education of the household head, occupational dummies, and interactions of age and occupation with education. Then we computed the variance of the residuals from the income model for each year. For example, $V A R_{i 2010}$ (income uncertainty for household $i$ in year 2010) is the variance of the residual from income model (regressing income on lagged earnings, and demographic variables mentioned above) computed based on 2009 and 2010 data.

In the second part, we estimate the relationship between actual savings and weather risk. We estimated equations under different situations of annual and seasonal weather risks and variability. The dependent variable in the second part is household $i$ 's annual savings in year $t$. Total annual savings are computed by subtracting total annual food and nonfood expenditures from total annual incomes. To compute the weather risk variable, we collected village-level weather-related information from ICRISAT. We computed weather risk as a coefficient of variation (CV) of rainfall based on village-level monthly data for 2009 to 2012 and then matched each household with the appropriate village. ${ }^{8}$ We also computed seasonal weather risk by computing CVs for Kharif and Rabi seasons. The $\mathrm{CV}$ of the Kharif season is computed from the monthly rainfall data from May to October; the CV of the Rabi season is computed from the monthly rainfall data from November to March.

\section{7 | RESULTS AND DISCUSSION}

Table 2 shows the estimation of Equation 11 for a range of estimators. For instance, column (2) shows estimates from OLS. The lagged changes in consumption, $\Delta c_{i(t-1)}$, on the same column have a negative and significant effect on the current changes in consumption. This finding suggests that the coefficient $\gamma$ in Equations 10 and 11 is negative, indicating that the utility function exhibits habit formation or durability (Deaton, 1992). However, the coefficient for the precautionary savings component, $V A R_{i t}$, is not significant. Another important variable significant in the OLS regression is the land asset holding (represented by value of owned land plots), which has a significantly positive effect on changes in current consumption.

Column (3), Table 2, presents parameter estimates for a within-group estimator, taking into account fixed effects. The estimated value of $\gamma$ is still negative and statistically significant; however, the magnitude is smaller than the OLS estimates. Recall that the fixed effect or within-group estimators in the case of data with short time dimension may likely suffer from a bias (Nickell, 1981). The coefficient of $V A R_{i t}$ is not significant. However, estimates may be biased if there is an endogeneity of lagged differences in consumption or if they have measurement error. Column (4), Table 2, presents parameter estimates from first-differenced GMM procedure. First differencing is 
T A B L E 2 Euler equation estimates for alternative models, rural India, 2009-2013

\begin{tabular}{|llccc} 
& $\begin{array}{l}\text { Model 1 } \\
\text { Pooled OLS } \\
\text { (level form) }\end{array}$ & $\begin{array}{l}\text { Model 2 } \\
\text { Within (FE) } \\
\text { estimation }\end{array}$ & $\begin{array}{l}\text { Model 3 } \\
\text { First-differenced } \\
\text { GMM }\end{array}$ & $\begin{array}{l}\text { Model 4 } \\
\text { System } \\
\text { GMM }\end{array}$ \\
\hline Consumption $\Delta c_{i(t-1)}$ & $-0.545^{* *}$ & $-0.443^{* *}$ & $-0.499 * *$ & $-0.545^{* *}$ \\
$V A R_{i t}\left(10^{-3}\right)$ & $(-3.84)$ & $(-10.19)$ & $(-2.86)$ & $(-3.84)$ \\
& -0.0024 & -0.009 & 0.010 & 0.0024 \\
\hline
\end{tabular}

Household/household head characteristics

\begin{tabular}{|c|c|c|c|c|}
\hline Value of owned plots & $\begin{array}{l}0.010 * * \\
(0.02)\end{array}$ & $\begin{array}{l}0.014 * * \\
(2.11)\end{array}$ & $\begin{array}{l}0.0260 * \\
(1.76)\end{array}$ & $\begin{array}{l}0.0009 \\
(0.20)\end{array}$ \\
\hline Household Size & NS & NS & NS & NS \\
\hline Female & NS & Dropped & NS & NS \\
\hline Age of the household head & $\mathrm{NS}$ & Dropped & NS & NS \\
\hline High school & NS & Dropped & NS & NS \\
\hline College & NS & Dropped & NS & NS \\
\hline More than college & NS & Dropped & NS & NS \\
\hline$m 1$ & & & -1.37 & -1.63 \\
\hline Hansen test of over-identify & trictions & & 14.50 & 16.84 \\
\hline$p$ value & & & 0.206 & 0.207 \\
\hline No. of observations & 933 & 933 & 564 & 933 \\
\hline
\end{tabular}

Note. $t$ statistics in parentheses. ${ }^{*} p<0.10$; ${ }^{*} p<0.05$. NS: nonsignificant. $V A R_{i t}$ is proxy for household income risk. Dependent variable is total annual household consumption in thousands. Year dummies were included in each equation. A constant term was included in Model 1 and Model 2. Model 3: Arellano and Bond (1991) estimator obtained from two-step estimation with corrected standard errors and statistics. Model 4: Two-step system GMM (Blundell \& Bond, 1998) estimation with corrected standard errors. Instruments: Instruments in the model (3): $c_{i(t-2)}, V A R_{i(t-2)}$ and $X_{i t}$, household characteristics; in model (4): the $c_{i(t-2)}, V A R_{i(t-2)}$ and $X_{i t}$ for the differenced equation; $c_{i(t-2)}, V A R_{i(t-2)}$ and $X_{i t}$ for the level equation. $\mathrm{m} 1$ is the test for serial correlation in the first differenced residuals under the null of no serial correlation.

useful in controlling fixed effects and time-invariant component of measurement error, which may likely affect both $V A R_{i t}$ and $\Delta c_{i(t-1)}$. However, time-variant measurement error and an endogeneity problem associated with $V A R_{i t}$ and $\Delta c_{i(t-1)}$ may still remain. Therefore, we instrumented these variables $\left(V A R_{i t}\right.$ and $\left.\Delta c_{i(t-1)}\right)$ with appropriate lags (see table note, Table 2). A negative and significant coefficient on $\Delta c_{i(t-1)}$ indicates evidence of habit formation or durability in consumption. However, we cannot conclude the precautionary motive as the coefficient of $V A R_{i t}$ is not significant.

Table 2 also shows the test results that we conducted to evaluate whether our model is correctly specified. We performed two tests: a Sargan-Hansen test ( $J$ statistic) for over-identifying restrictions and a serial correlation test for second-order serial correlation in residuals $(\mathrm{m} 2)$. The overidentifying restriction test allows us to evaluate the validity of the instruments. If the model is correctly specified, the variables in the instrument set must be uncorrelated with error term $e_{i t}$ (Equation 11). The serial correlation test of second degree $(\mathrm{m} 2)$ allows us to test the legitimacy of variables in the $t-2$ year as instruments. The result in Table 2 show no signs for second-order serial correlation at the 5 percent level of significance $(J$ statistic $=1.37)$, suggesting that our estimates do not violate the generalization of Weil's (1993) model. Although we do not have prior knowledge to believe that our model is affected by weak instrument bias, column (5) in Table 2 
presents the estimates of Equation 11 using the system GMM estimator. The coefficient on $\Delta c_{i(t-1)}$ is very similar to those obtained from the first-differenced GMM estimator (column 4, Table 2). Finally, using a random effects model, we performed a regression-based formal test by regressing first differences of potential endogenous variables $\Delta c_{i(t-1)}$ and $V A R_{i t}$ on all exogenous variables and remaining instruments, and we found that the instruments have high explanatory power.

The household's income generation process is computed using variables presented in Appendix Table A1, then the predicted residual from each equation for respective years is used to compute income uncertainty $\left(V A R_{i t}\right)$. We used age, education, occupation and interaction of occupation with education, and age as determinants of household income (Table A1).

From Table 2, we found that the habit formation component $(\gamma)$ is consistently significant and negative across all estimates suggesting a significant habit formation in consumption of rural households. The poorly determined consumption response for income uncertainty (coefficients of $V A R_{i t}$ ) indicates no sufficient evidence for smoothing through adjustment in consumption among rural households. However, a positive and significant land asset holding variable suggest a positive wealth effect on consumption-having a greater land asset or higher value of land holding enables positive consumption growth among rural households.

In the second part of the paper, we estimated actual savings equations. The savings variable for household $i$ in our analysis is computed as a difference between households' total incomes and their total food and nonfood expenditures. We estimated savings equations under annual and seasonal weather variabilities. First, we included weather variability (weather risk) computed based on monthly rainfall data from January to December of the respective year (annual CV) as a proxy for income variability and evaluated rural Indian households' savings response to weather risk. Second, we used variability in seasonal rainfall using separate CVs for the Kharif and Rabi seasons. In both models, we control for lagged savings, lagged household incomes, demographic variables, and interaction of weather variability variables with occupation.

Table 3 presents the parameter estimates of the savings equation, using two different methods: pooled OLS and dynamic generalized least squares (dynamic GLS). Table 3, columns (2) and (3), show the results of the savings equation for the model using variability in monthly rainfall using months from January to December across two methods. Columns (4) and (5) present model results using variability in monthly rainfall during the Kharif season months as an indicator of seasonal weather risk. Columns (6) and (7) present model results using variability in monthly rainfall during the Rabi season months as an indicator of seasonal weather risk. Our results across two methods and under both annual and seasonal weather risks consistently show that weather risk significantly influences the savings of rural households, except for variability in the Rabi season months. A consistent negative coefficient of weather variables across all methods and for both risks suggest that Indian rural households draw from their savings or non-save when subjected to higher weather risks-perhaps deriving their stocks for consumption leading to no saving when faced with higher weather risks in the short-run. These findings are consistent with Paxson (1992) who used rainfall variability as a proxy for income variability in the case of Thai farmers and found that change in savings with variance in income was negative. Additionally, our results in Table 3 show that current savings have a significant positive association with lagged savings $S_{i(t-1)}$ and lagged income $y_{i(t-1)}$. This is consistent with Alessie and Lusardi (1997), who concluded that current savings depend not only on income changes and income risks but also on past savings. Additionally, our results suggest that household's participation in off-farm work positively influences savings. This indicates that the households involved in offfarm activities and deriving off-farm incomes save higher than those not involved. Our results, finding negative effects of weather risk and positive effects of off-farm work on rural household 
T A B LE 3 Estimates of savings equations under annual and seasonal weather risks, rural India, 2009-2012

\begin{tabular}{|c|c|c|c|c|c|c|}
\hline \multirow[b]{2}{*}{$\begin{array}{l}\text { Dependent variable: } \\
\text { Savings }\left[S_{i t}\right] \text {, in logs }\end{array}$} & \multicolumn{2}{|c|}{$\begin{array}{l}\text { Savings under weather } \\
\text { risk (model using } \\
\text { variability in monthly } \\
\text { rainfall, annual) } \\
\end{array}$} & \multicolumn{4}{|c|}{$\begin{array}{l}\text { Savings under weather risk } \\
\text { (models using variability } \\
\text { in monthly rainfall, seasonal) } \\
\end{array}$} \\
\hline & $\begin{array}{l}\text { Pooled } \\
\text { OLS }\end{array}$ & $\begin{array}{l}\text { Dynamic } \\
\text { GLS }\end{array}$ & $\begin{array}{l}\text { Pooled } \\
\text { OLS }\end{array}$ & $\begin{array}{l}\text { Dynamic } \\
\text { GLS }\end{array}$ & $\begin{array}{l}\text { Pooled } \\
\text { OLS }\end{array}$ & $\begin{array}{l}\text { Dynamic } \\
\text { GLS }\end{array}$ \\
\hline Lagged savings ${ }^{\mathrm{a}}\left[S_{i(t-1)}\right]$ & $\begin{array}{l}0.209 * * \\
(3.11)\end{array}$ & $\begin{array}{l}0.165^{* * *} \\
(1.99)\end{array}$ & $\begin{array}{l}0.229 * * \\
(3.45)\end{array}$ & $\begin{array}{l}0.189^{* *} \\
(2.29)\end{array}$ & $\begin{array}{l}0.207 * * \\
(3.08)\end{array}$ & $\begin{array}{l}0.160^{*} \\
(1.83)\end{array}$ \\
\hline Lagged income $^{\mathrm{a}}\left[y_{i(t-1)}\right]$ & $\begin{array}{l}0.829 * * \\
(7.70)\end{array}$ & $\begin{array}{l}0.861^{* *} \\
(6.32)\end{array}$ & $\begin{array}{l}0.796^{* *} \\
(7.42)\end{array}$ & $\begin{array}{l}0.827^{* *} \\
(6.11)\end{array}$ & $\begin{array}{l}0.809 * * \\
(7.20)\end{array}$ & $\begin{array}{l}0.844 * * \\
(5.99)\end{array}$ \\
\hline Value of owned plots ${ }^{\mathrm{a}}$ & $\begin{array}{l}-0.021 \\
(-0.46)\end{array}$ & $\begin{array}{l}-0.016 \\
(-0.31)\end{array}$ & $\begin{array}{l}-0.0245 \\
(-0.53)\end{array}$ & $\begin{array}{l}-0.020 \\
(-0.410)\end{array}$ & $\begin{array}{l}-0.0602 \\
(-1.23)\end{array}$ & $\begin{array}{l}-0.057 \\
(-1.17)\end{array}$ \\
\hline Female & $\begin{array}{l}-0.197 \\
(-1.44)\end{array}$ & $\begin{array}{l}-0.211 \\
(-1.30)\end{array}$ & $\begin{array}{l}-0.202 \\
(-1.48)\end{array}$ & $\begin{array}{l}-0.216 \\
(-1.30)\end{array}$ & $\begin{array}{l}-0.317 * * \\
(-2.15)\end{array}$ & $\begin{array}{l}-0.333^{*} \\
(-1.82)\end{array}$ \\
\hline Household size & $\begin{array}{l}0.009 \\
(0.52)\end{array}$ & $\begin{array}{r}0.010 \\
(0.63)\end{array}$ & $\begin{array}{l}-0.011 \\
(-0.63)\end{array}$ & $\begin{array}{l}0.0116 \\
(0.740)\end{array}$ & $\begin{array}{r}0.007 \\
(0.38)\end{array}$ & $\begin{array}{l}0.008 \\
(0.48)\end{array}$ \\
\hline Farming as main occupation & $\begin{array}{l}-0.712 * \\
(-1.64)\end{array}$ & $\begin{array}{l}-0.651^{*} \\
(1.74)\end{array}$ & $\begin{array}{l}-0.439 \\
(-1.35)\end{array}$ & $\begin{array}{l}-0.394 \\
(-1.31)\end{array}$ & $\begin{array}{l}-0.286 \\
(-0.560)\end{array}$ & $\begin{array}{l}-0.288 \\
(-0.570)\end{array}$ \\
\hline Service as main occupation & $\begin{array}{l}-0.658 \\
(-1.35)\end{array}$ & $\begin{array}{l}-0.619 \\
(-1.55)\end{array}$ & $\begin{array}{l}-0.534 \\
(-1.50)\end{array}$ & $\begin{array}{l}-0.514 \\
(-1.47)\end{array}$ & $\begin{array}{l}-0.107 \\
(-0.150)\end{array}$ & $\begin{array}{l}-0.091 \\
(-0.110)\end{array}$ \\
\hline $\begin{array}{l}\text { Years of education, } \\
\text { HH head }\end{array}$ & $\begin{array}{l}-0.014^{*} \\
(-1.74)\end{array}$ & $\begin{array}{l}-0.015^{* *} \\
(-1.93)\end{array}$ & $\begin{array}{l}-0.014 * \\
(-1.71)\end{array}$ & $\begin{array}{l}-0.015^{*} \\
(1.89)\end{array}$ & $\begin{array}{l}-0.017 * * \\
(-2.01)\end{array}$ & $\begin{array}{l}-0.019 * * \\
(-2.29)\end{array}$ \\
\hline $\begin{array}{l}\text { Participation in } \\
\text { off-farm work }\end{array}$ & $\begin{array}{l}0.092^{* *} \\
(1.98)\end{array}$ & $\begin{array}{l}0.0886^{*} \\
(1.76)\end{array}$ & $\begin{array}{l}0.092 * \\
(1.67)\end{array}$ & $\begin{array}{l}0.089^{*} \\
(1.77)\end{array}$ & $\begin{array}{l}0.073 \\
(0.84)\end{array}$ & $\begin{array}{l}0.069 \\
(0.84)\end{array}$ \\
\hline $\begin{array}{l}\text { Weather risk: variability in } \\
\text { monthly rainfall, annual }^{\mathrm{a}}\end{array}$ & $\begin{array}{l}-1.335^{* *} \\
(-3.42)\end{array}$ & $\begin{array}{l}-1.291 * * \\
(-3.70)\end{array}$ & & & & \\
\hline $\begin{array}{l}\text { Farming occup. } \times \text { variability } \\
\text { in monthly rainfall, annual }\end{array}$ & $\begin{array}{l}0.874 * \\
(1.71)\end{array}$ & $\begin{array}{l}0.819^{*} \\
(1.75)\end{array}$ & & & & \\
\hline $\begin{array}{l}\text { Service occup. } \times \text { variability } \\
\text { in monthly rainfall, annual }\end{array}$ & $\begin{array}{r}0.737 \\
(1.32)\end{array}$ & $\begin{array}{l}0.708 \\
(1.39)\end{array}$ & & & & \\
\hline $\begin{array}{l}\text { Weather risk: variability in } \\
\text { seasonal monthly } \\
\text { rainfall, Kharif }\end{array}$ & & & $\begin{array}{l}-0.827^{* *} \\
(-2.95)\end{array}$ & $\begin{array}{l}-0.784^{* *} \\
(-2.71)\end{array}$ & & \\
\hline $\begin{array}{l}\text { Farming occup. } \times \text { variability } \\
\text { in seasonal monthly } \\
\text { rainfall, Kharif }\end{array}$ & & & $\begin{array}{l}0.596 \\
(1.44)\end{array}$ & $\begin{array}{l}0.525 \\
(1.32)\end{array}$ & & \\
\hline $\begin{array}{l}\text { Service occup. } \times \text { variability } \\
\text { in seasonal monthly } \\
\text { rainfall, Kharif }\end{array}$ & & & $\begin{array}{c}0.640 \\
(1.42)\end{array}$ & $\begin{array}{c}0.613 \\
(1.35)\end{array}$ & & \\
\hline
\end{tabular}


TABLE 3 (Continued)

\begin{tabular}{|c|c|c|c|c|c|c|}
\hline \multirow[b]{2}{*}{$\begin{array}{l}\text { Dependent variable: } \\
\text { Savings }\left[S_{i t}\right] \text {, in logs }\end{array}$} & \multicolumn{2}{|c|}{$\begin{array}{l}\text { Savings under weather } \\
\text { risk (model using } \\
\text { variability in monthly } \\
\text { rainfall, annual) }\end{array}$} & \multicolumn{4}{|c|}{$\begin{array}{l}\text { Savings under weather } \text { risk }^{\mathbf{b}} \\
\text { (models using variability } \\
\text { in monthly rainfall, seasonal) }\end{array}$} \\
\hline & $\begin{array}{l}\text { Pooled } \\
\text { OLS }\end{array}$ & $\begin{array}{l}\text { Dynamic } \\
\text { GLS }\end{array}$ & $\begin{array}{l}\text { Pooled } \\
\text { OLS }\end{array}$ & $\begin{array}{l}\text { Dynamic } \\
\text { GLS }\end{array}$ & $\begin{array}{l}\text { Pooled } \\
\text { OLS }\end{array}$ & $\begin{array}{l}\text { Dynamic } \\
\text { GLS }\end{array}$ \\
\hline $\begin{array}{l}\text { Weather risk: variability } \\
\text { in seasonal monthly } \\
\text { rainfall, } R a b i^{\text {a }}\end{array}$ & & & & & $\begin{array}{l}-0.444 \\
(-0.98)\end{array}$ & $\begin{array}{l}-0.457 \\
(-1.08)\end{array}$ \\
\hline $\begin{array}{l}\text { Service occup. } \times \text { variability } \\
\text { in seasonal monthly rainfall, } R a b i\end{array}$ & & & & & $\begin{array}{l}0.143 \\
(0.56)\end{array}$ & $\begin{array}{r}0.141 \\
(0.57)\end{array}$ \\
\hline $\begin{array}{l}\text { Farming occup. } \times \text { variability } \\
\text { in seasonal maonthly rainfall, } R a b i\end{array}$ & & & & & $\begin{array}{r}0.042 \\
(0.12)\end{array}$ & $\begin{array}{r}0.036 \\
(0.09)\end{array}$ \\
\hline Constant & $\begin{array}{l}-0.052 \\
(-0.06)\end{array}$ & $\begin{array}{l}-0.029 \\
(-0.02)\end{array}$ & $\begin{array}{l}-0.567 \\
(-0.61)\end{array}$ & $\begin{array}{l}-0.524 \\
(-0.42)\end{array}$ & $\begin{array}{l}0.604 \\
(0.59)\end{array}$ & $\begin{array}{l}0.687 \\
(0.53)\end{array}$ \\
\hline Number of observations & 583 & 583 & 583 & 583 & 531 & 531 \\
\hline
\end{tabular}

Note. Models in columns (2)-(7) include a set of year dummies in each equations; $t$ statistics in parentheses; * $p<0.10$; $* * p<0.05$. Indicates variables are in log form. Coefficient of variation (CV) of monthly rainfall is used as the measure of weather risk. For annual variability, CV is computed based on 12 month (Jan. to Dec.) monthly rainfall village-level data for the respective year. ${ }^{\mathrm{b}} \mathrm{CV}$ of Kharif season computed from the monthly rainfall data from May to October; CV of Rabi season computed from the monthly rainfall data from November to March.

savings, together may suggest that rural households adjust their saving-non-saving behavior through on- and off-farm activities intended to minimize risk. This is in line with Kochar (1999) who concluded that the ability of households to shift from own-farm to off-farm work in response to agricultural or crop income risks reduces the variability in household income and their need to rely on savings to smooth consumption.

\section{8 | SUMMARY AND CONCLUSIONS}

We analyzed the consumption and saving decisions of rural Indian households using panel data methods. We used household-level data for 2009 to 2012 for rural households in India. In the first part of the paper, we tested for precautionary savings behavior of the households while accounting for habit formation. We derived a Euler equation in which consumption changes are a function of past consumption and labor income risk. We found that lagged changes in consumption have a significant adverse effect on current changes in consumption. This finding indicates that the utility function of rural Indian households exhibits habit formation. The findings of habit formation are consistently significant across different panel model estimators. Our study also shows that a model without accounting for habit formation would lead to biased estimates. Finally, the presence of habit formation indicates that preferences are not separable over time; consumption studies with the assumption of separable preferences may lead to biased estimates - a finding that empirically contradicts the life-cycle model.

In the second part of the paper, we estimated savings of rural households. We estimated saving models under annual and seasonal weather risks. Our study finds that rural households tend to save 
less or non-save under higher annual and seasonal weather risks, which indicates that the households may derive their stock of savings for consumption purpose during times with higher weather risks leading to non-savings. Specifically rural households such as in our sample, depend on agriculture for their livelihood, and agriculture is very vulnerable to weather conditions. Additionally, we find that the educational attainment of the head of household has a significant negative effect on savings. We found that participation in off-farm work is significant and positively influencing savings. Together, this indicates that rural households with ability to derive income from off-farm activities may need to rely less on their savings.

Given the large contribution of agriculture to the Indian economy and agriculture's linkage with other sectors, this research implies that variations in incomes of rural households are associated with agricultural income and weather could have a tremendous impact on the welfare of the rural population. For rural households, the problem is compounded because they are prone to agricultural income shocks caused by weather and are not able to ensure adequately against weather vagaries. Overall our analysis provides some valuable insights to policymakers and researchers. First, to stabilize income or enhance consumption and food security of rural households, policymakers should design programs or incentives that encourage agricultural diversification, weather-based insurance, subsidies, access to credits, and crop loss minimization. Second, policymakers need to design and implement policies that boost the earning capacity of rural households. For example, the government can provide incentives for alternative income generation activities and skills training that enable rural households to enhance their current consumption by reducing future or postponed consumption. Another unique finding from this study is farming households' dependence on the nonfarm economy and their link to the economic conditions in the nonfarm sector. Therefore, we would argue that a robust and vibrant nonfarm economy is beneficial to rural households not only in India but also in other developing countries.

\section{CONFLICT OF INTEREST}

The authors declare that they have no conflict of interest.

\section{ENDNOTES}

${ }^{1}$ Theoretically, either quadratic utility function or negative exponential utility is assumed to have a closed-form solution. Alessie and Lusardi (1997) derived a closed-form solution allowing for habit formation and uncertainty using a negative exponential utility function.

${ }^{2}$ Weil's (1993) model represents a hybrid model. In his model preferences are isoelastic intertemporally, but exponential with respect to the risk component. Guariglia and Rossi (2002) added a habit formation component to Weil's model and derived a closed-form solution in the presence of labor income uncertainty.

${ }^{3}$ In these countries, insurance markets are inefficient or absent.

${ }^{4}$ Dynan (2000) estimated a first-order condition of habit formation using household expenditure data.

${ }^{5}$ In urban areas, 77 percent of savings is in land and 18 percent in buildings.

${ }^{6}$ U.S. $\$ 1.00=66$ Indian Rupees (Rs.).

${ }^{7}$ In the case of weak instruments, the estimates are likely to be biased. Blundell and Bond (1998) indicated this may be an issue for first-differenced GMM and hence developed an alternative estimator, the system GMM, which consists of combining the first-differenced equations with equations in levels.

${ }^{8}$ Village-level rainfall data for a few villages was missing for 2009 except for first generation VDSA villages (Aurapalle, Dokur, JC Agrahaarm, Kalman, Kanzara, Kinkhed and Shirapur) since the second generation VDSA project started in 2009 and the rain gauges for the new villages were installed only in 2010. For missing villages, we used the 2009 district-level rainfall of the respective villages from VDSA meso database. 


\section{REFERENCES}

Abass, A., Ndunguru, G., Mamiro, P., Alenkhe, B., Mlingi, N., \& Bekunda, M. (2014). Post-harvest food losses in a maize-based farming system of semi-arid savannah area of Tanzania. Journal of Stored Products Research, 57, 49-57.

Alessie, R., \& Lusardi, A. (1997). Consumption, saving and habit formation. Economics Letters, 55(1), $103-108$.

Alessie, R., \& Teppa, F. (2010). Saving and habit formation: Evidence from Dutch panel data. Empirical Economics, 38(2), 385-407.

Arellano, M., \& Bond, S. (1991). Some tests of specification for panel data: Monte Carlo evidence and an application to employment equations. Review of Economic Studies, 58(2), 277-297.

Arellano, M., \& Bover, O. (1995). Another look at the instrumental-variable estimation of error-components models. Journal of Econometrics, 68(1), 29-52.

Athukorala, P., \& Sen, K. (2002). Saving, investment, and growth in India. Oxford, U.K.: Oxford University Press.

Blundell, R., \& Bond, S. (1998). Initial conditions and moment restrictions in dynamic panel data models. Journal of Econometrics, 87(1), 115-143.

Carroll, C. D., Overland, J., \& Weil, D. N. (2000). Saving and growth with habit formation. American Economic Review, 90(3), 341-355.

Datt, G., \& Ravallion, M. (2002). Has India's post-reform economic growth left the poor behind? Journal of Economic Perspectives, 16(3), 89-108.

Deaton, A. (1992). Understanding consumption. Oxford, U.K.: Oxford University Press.

Dynan, K. E. (2000). Habit formation in consumer preferences: Evidence from panel data. American Economic Review, 90(3), 391-406.

Flavin, M. (1981). The adjustment of consumption to changing expectations about future income. Journal of Political Economy, 89(5), 974-1009.

Friedman, M. (1957). A theory of the consumption function. Princeton, NJ: Princeton University Press.

Gadgil, S. (1996). Climate change and agriculture_an Indian perspective. In Y. R. Abrol, S. Gadgil, \& G. B. Pant (Eds.), Climate variability and agriculture (pp. 1-18). New Delhi, India: Narosa.

Garcia, R., Lusardi, A., \& Ng, S. (1997). Excess sensitivity and asymmetries in consumption: An empirical investigation. Journal of Money, Credit, and Banking, 29(2), 154-176.

Government of India. (2011). Socio-economic, and caste census 2011. Retrieved from http://www.secc.gov.in/ reportlistContent

Government of India. (2013). Census of India 2011. Retrieved from http://censusindia.gov.in/

Government of India. (2014). Level and pattern of consumer expenditure (NSS [National Sample Survey Office] Report No. 555-68/1.0/1). Ministry of Statistics and Programme Implementation, New Delhi, India.

Greg, E. E., Bnam, B. E., William, M. F., \& Duru, E. J. C. (2011). Climate change, food security and agricultural productivity in African: Issues and policy directions. International Journal of Humanities and Social Science, 1 (21), 205-223.

Guariglia, A., \& Rossi, M. (2002). Consumption, habit formation, and precautionary saving: Evidence from the British Household Panel Survey. Oxford Economic Papers, 54(1), 1-19.

Hall, R. (1978). Stochastic implications of the life-cycle/permanent income hypothesis: Theory and evidence. Journal of Political Economy, 86(6), 971-987.

Hall, R., \& Mishkin, F. (1982). The sensitivity of consumption to transitory income: Estimates from panel data on households. Econometrica, 50(2), 461-482.

Hussain, I., \& Hanjra, M. (2004). Irrigation and poverty alleviation: Review of the empirical evidence. Irrigation and Drainage, 53(1), 1-15.

Jha, S., \& Prasad, E., \& Terada-Hagiwara, A. (2009). Saving in Asia and issues for rebalancing growth (Asia Development Bank Economics Working Paper Series, No. 162). Retrieved from http://adb.org/sites/default/files/ pub/2009/Economics-WP162.pdf

Jodha, N. S., Asolan, M., \& Ryan, J. G. (1977). Village study methodology and resource endowments of the selected villages in ICRISAT's village level studies (Economic Program Occasional Paper No. 16). ICRISAT, Hyderabad, India.

Kazarosian, M. (1997). Precautionary savings-a panel study. Review of Economics and Statistics, 79(2), $241-247$.

Khanal, A., Mishra, A., \& Bhattarai, M. (2017). Assessing the impact of weather risk on land use intensity: A nonstationary and dynamic panel modelling approach. Land Economics, 93(1), 40-58. 
Khanal, A., Mishra, A., \& Keithly, W. (2016). Heterogeneity in food demand among rural Indian households: The role of demographics. Canadian Journal of Agricultural Economics, 64(3), 517-544.

Kochar, A. (1999). Smoothing consumption by smoothing income: Hours-of-work responses to idiosyncratic agricultural shocks in rural India. Review of Economics and Statistics, 81(1), 50-61.

Krishna, K. K., Rupa, K. K., Ashrit, R., Deshpande, N. R., \& Hansen, J. W. (2004). Climate impacts on Indian agriculture. International Journal of Climatology, 24(11), 1375-1393.

Kumar, S., Naresh, P. K., Aggarwal, D. N., Rani, R. S., Chauhan, N., \& Jain, S. (2014). Vulnerability of wheat production to climate change in India. Climate Research, 59(3), 173-187.

Landes, M. R., \& Burfisher, M. E. (2009). Growth and equity effects of agricultural marketing efficiency gains in India (Economic Research Services, ERR No. 89). U.S. Department of Agriculture, Washington, DC.

Lobell, D. B., Schlenker, W., \& Costa-Roberts, J. (2011). Climate trends and global crop production since 1980. Science, 333(6042), 616-620.

McKenzie, D. (2001). Consumption growth in a booming economy: Taiwan 1976-96 (Yale Economic Growth Center, Discussion Paper No. 823). Yale University, New Haven, CT.

Meghir, C., \& Weber, G. (1996). Intertemporal nonseparability or borrowing restrictions? A disaggregate analysis using a US consumption panel. Econometrica, 64(5), 1151-1181.

Mishra, A. K., \& Goodwin, B. K. (1997). Farm income variability and the supply of off-farm labor. American Journal of Agricultural Economics, 79(3), 880-887.

Mishra, A. K., Uematsu, H., \& Powell, R. (2012). Precautionary wealth and income uncertainty: A household-level analysis. Journal of Applied Economics, 15(2), 353-369.

Modigliani, F., \& Brumberg, R. (1954). Utility analysis and the consumption function: An interpretation of the crosssection data. In K. Kurihara (Ed.), Post-Keynesian economics. New Brunswick, NJ: Rutgers University Press.

Mondal, P., Jain, M., Robertson, A., Galford, G., Small, C., \& DeFries, T. (2014). Winter crop sensitivity to interannual climate variability in central India. Climatic Change, 126(1), 61-76.

Morduch, J. (1995). Income smoothing and consumption smoothing. Journal of Economic Perspectives, 9(3), 103114.

Nickell, S. (1981). Biases in dynamic models with fixed effects. Econometrica, 49(6), 1417-1426.

Paxson, C. H. (1992). Using weather variability to estimate the response of savings to transitory income in Thailand. The American Economic Review, 82(10), 15-33.

Pollak, R. A. (1970). Habit formation, and dynamic demand functions. Journal of Political Economy, 78(4), 745-763.

Rhee, W. (2004). Habit formation and precautionary saving: Evidence from the Korean household panel studies. Journal of Economic Development, 29(2), 1-19.

Shea, J. (1995). Myopia, liquidity constraints, and aggregate consumption: A simple test. Journal of Money, Credit, and Banking, 27(3), 798-805.

Webster, P. J., Magana, V. O., Palmer, T. N., Shukla, J., Tomas, R. A., Yanai, M., \& Yasunari, T. (1998). Monsoons: Processes, predictability, and the prospects for prediction. Journal of Geophysical Research, 103(C7), 14451-14510.

Weil, P. (1993). Precautionary savings and the permanent income hypothesis. Review of Economic Studies, 60(2), $367-381$.

How to cite this article: Khanal AR, Mishra AK, Nedumaran S. Consumption, habit formation, and savings: Evidence from a rural household panel survey. Rev Dev Econ. 2018;00:1-19. https://doi.org/10.1111/rode.12536 


\section{APPENDIX}

T A B LE A 1 Equation for household's income generation process for respective year ${ }^{a}$ (first-stage regression)

\begin{tabular}{|c|c|c|c|c|c|c|c|c|}
\hline \multirow[b]{2}{*}{ Variables } & \multicolumn{2}{|l|}{ Year 2009} & \multicolumn{2}{|l|}{ Year 2010} & \multicolumn{2}{|l|}{ Year 2011} & \multicolumn{2}{|l|}{ Year 2012} \\
\hline & Coefficient & $t$ stat. & Coefficient & $t$ stat & Coefficient & $t$ stat. & Coefficient & $t$ stat. \\
\hline Constant & 138.0 & 1.50 & $140.20 *$ & 1.81 & $123.80^{*}$ & 1.65 & $123.00 *$ & 1.82 \\
\hline Household size & -6.375 & -1.56 & -2.504 & -0.71 & -1.439 & -0.42 & -0.596 & -0.20 \\
\hline $\begin{array}{l}\text { Age of the household } \\
\text { (HH) head }\end{array}$ & -2.278 & -1.60 & -1.195 & -1.04 & -0.255 & -0.24 & -0.162 & -0.17 \\
\hline $\begin{array}{l}\text { Gender (= } 1 \text { if female) } \\
\text { of } \mathrm{HH} \text { head }\end{array}$ & $193.8^{* *}$ & 3.71 & $96.83^{* *}$ & 2.25 & $76.76^{*}$ & 1.82 & $60.01 *$ & 1.67 \\
\hline $\begin{array}{l}\text { Years of formal } \\
\text { education }\end{array}$ & -0.011 & -0.00 & 1.562 & 0.46 & 1.286 & 0.40 & 0.291 & 0.10 \\
\hline $\begin{array}{l}\text { Service as a main } \\
\text { occupation }\end{array}$ & -201.00 & -1.38 & 109.20 & -1.07 & -78.85 & -0.89 & -75.23 & -0.96 \\
\hline $\begin{array}{l}\text { Farming as a main } \\
\text { occupation }\end{array}$ & $-194.40^{* *}$ & -2.21 & -111.80 & -1.51 & -79.59 & -1.13 & -80.81 & -1.28 \\
\hline \multicolumn{9}{|l|}{$\begin{array}{l}\text { (Base occupation: } \\
\text { business/enterprise) }\end{array}$} \\
\hline $\begin{array}{l}\text { Distance to work } \\
\text { place }(\mathrm{km})\end{array}$ & $0.324 *$ & 1.73 & 0.135 & 0.84 & $0.215^{*}$ & 1.65 & $0.250 * *$ & 2.06 \\
\hline $\begin{array}{l}\text { Service_occupation } \\
\times \text { age }\end{array}$ & 3.264 & 1.15 & 2.426 & 1.20 & 1.619 & 0.93 & 1.566 & 1.03 \\
\hline $\begin{array}{l}\text { Farming_occupation } \\
\times \text { age }\end{array}$ & $3.953 * *$ & 2.36 & $2.564 *$ & 1.87 & 1.634 & 1.27 & 1.697 & 1.48 \\
\hline $\begin{array}{l}\text { Service_occupation } \times \\
\text { education }\end{array}$ & 1.849 & 0.29 & -0.557 & -0.12 & -0.363 & -0.09 & 1.699 & 0.46 \\
\hline $\begin{array}{l}\text { Farming_occupation } \times \\
\text { education }\end{array}$ & 1.129 & 0.24 & -0.142 & -0.04 & 0.561 & 0.15 & 0.932 & 0.29 \\
\hline Number of observations & 653 & & 1,001 & & 1,378 & & 1,795 & \\
\hline $\begin{array}{l}\text { Household income } \\
\text { uncertainty (predicted } \\
\text { mean residual } \\
\text { variance, } V A R_{i t},{ }^{\prime} 000 \text { ) }\end{array}$ & 65.28 & & 63.53 & & 63.27 & & 63.28 & \\
\hline
\end{tabular}

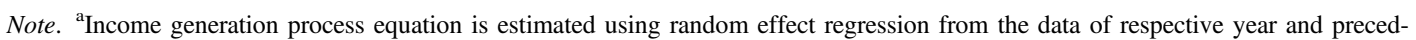
ing years: data from 2009 and 2010 were used for 2010 equation; data from 2009, 2010, and 2011 for 2011 equation; data from 2009, 2010, 2011, and 2012 for 2012 equation; since 2009 was the first year in our panel stream, OLS regression was estimated for 2009 equation. 